\title{
Environmental performance comparison of parboiled rice production
}

\author{
E Nadeeshani and MY Gunasekera" \\ Department of Chemical and Process Engineering, Faculty of Engineering, University of Moratuwa, Moratuwa.
}

Submitted: 01 March 2019; Revised: 30 November 2019; Accepted: 08 April 2020

\begin{abstract}
Parboiling is a process that paddy undergoes in rice production which consumes energy, water and other environmental resources. This paper presents an assessment of environmental performance of paddy parboiling methods adopted in Sri Lanka by using life cycle assessment approach. Two hot soaking methods utilising mechanical drying and sun drying and one parboiling paddy method where cold soaking is utilised are considered for comparison in this assessment. For all methods, processes from paddy harvesting to rice cooking are included in the system with a functional unit of production of one ton of parboiled rice. According to the results, the parboiling method with hot soaking and mechanical drying showed acidification and human toxicity impacts, $0.430 \mathrm{~kg} \mathrm{SO}_{2}$ eq. and $0.552 \mathrm{~kg} \mathrm{1,4-DCB}$ eq. respectively. Cold soaking of paddy gave higher impact results in eutrophication compared to hot soaking.
\end{abstract}

Keywords: Environment, life cycle assessment, paddy processing, parboiled rice, pollution.

\section{INTRODUCTION}

Rice is the main food of the majority of population in Sri Lanka. Nearly $34 \%$ of total cultivated area in Sri Lanka is occupied with rice production and about 2.7 million tons of rice is produced annually. Out of the total rice consumption in Sri Lanka, 60\% is parboiled rice (Swarnasiri, 2014). Production of parboiled rice involves several steps. After harvesting, paddy undergoes operations such as threshing, winnowing, drying, washing, parboiling, milling, packaging and transportation, before it goes to the consumer where rice is cooked. Parboiling step in the parboiled paddy production consists of three major steps, namely, soaking, steaming and drying (Institute of Post-Harvest Technology, 2007). These operations consume energy, water and other environmental resources generating wastewater, air emissions and solid wastes resulting in adverse environmental impacts (CEA, 2001; Blengini \& Busto, 2009; Karunaratne \& Gunasekera, 2009).

To identify the environmental performance of the parboiled rice production process, similar to other food production processes, a life cycle environmental impact assessment is essential (Cherubini, 2010; Chang et al., 2012; Mohammadi et al., 2015). Life Cycle Assessment (LCA) is a methodology that can be used for assessing environmental impacts associated with resource consumption, emissions, energy inputs, and direct and indirect $\mathrm{GHG}$ emissions involved with life cycle of the process (ISO, 2006; Blengini \& Busto, 2009). Therefore, a LCA study enables the identification of the most environmentally friendly parboiled paddy production method among several alternatives (Roy et al., 2007; Roy et al., 2009a; Blengini \& Busto, 2009; Kwofie \& Ngadi, 2017).

Several LCA studies on rice parboil systems are available in literature. Kwofie and Ngadi (2017) have compared a rice parboiling system (RPS) used in a rural village with a newly developed integrated steaming and drying system (ISDS). These two methods use two different rice processing energy systems. Using LCA approach the rice processing steps, including soaking, steaming, drying and milling have been assessed. Their

*Corresponding author (manisha@uom.lk; (D https://orcid.org/0000-0002-0908-4912) 
analysis has shown that with the ISDS process up to $80 \%$ reduction in total environmental impact can be achieved (Kwofie \& Ngadi, 2017; Sala et al., 2017).

Blengini and Busto (2009) have applied LCA methodology to alternate rice production systems which include operations from paddy field to the supermarket. In their work alternate rice farming and food processing methods such as organic and upland farming and parboiling have been considered. Environmental loads of different rice production processes in Bangaladesh have been evaluated using the life cycle approach by Roy et al. (2007). The alternate methods compared include parboiling methods, namely, vessel and medium boiler and the untreated process where parboiling is not done. An environmental impact assessment has been carried out based on the inventory analysis. The system boundary has consisted of post-harvest processing steps, parboiling, de-husking, milling and cooking. The untreated process has shown better environmental performance compared to the other two methods. Roy et al. (2009a) have studied rice processing systems used in Japan in order to identify processes having less life cycle environmental impacts. Well and partially milled brown rice and germinated brown rice and parboiled milled rice processes have been compared. The comparison has shown that partially milled rice production is more environmentally friendly than other processes.

Few studies on LCA of rice production in Sri Lanka are available in literature. Raw rice production and parboiled rice production processes were analysed and compared by Kamalakkannan and Kulatunga (2018) studying two rice mills in Sri Lanka. The system boundary used in the LCA study for parboiled rice production includes paddy cleaning, parboiling, milling and polishing. The parboiling process in their work includes paddy soaking in hot water, steaming and electrical drying operations. The system boundary for raw rice production includes paddy cleaning, milling and polishing operations. Another study by Ariyarathna et al. (2016) presented a comparison of conventional and modern parboiled rice processing in Sri Lanka using LCA. In the conventional method, cold water soaking, steaming and sun drying were considered and in the modern method hot water soaking, steaming and mechanical drying were considered. The system boundary of the study includes paddy parboiling (soaking, steaming, drying) and milling. Here milling is referred to as destoning, de-husking and polishing operations together. The above studies in literature have analysed two alternatives of rice production practiced in Sri Lanka. However, a LCA could be more beneficial if more than two alternates are considered including many operations associated with rice production.

There are various operations involved in the production of rice that result in adverse environmental impacts. In order to identify and avoid these impacts, the operations that are involved with high environmental burdens in the production process need to be known. For this, all operations in rice production associated with environmental burdens should be assessed. This could be done by conducting a LCA with a system boundary capturing many operations as possible, for example, starting from harvesting operation of paddy to the consumption of rice. Further, the comparison of alternate parboiled paddy production methods facilitate the selection of the most environmentally sustainable method and for this as many alternate parboiling methods as possible need to be assessed and compared.

This work assesses the environmental impacts of three different parboiled paddy production methods adopted in Sri Lanka using the LCA approach. The methods looked at, include two modern methods which use hot soaking process and one semi modern method where cold soaking is used for parboiling paddy. The LCA system boundary includes processing steps involved from paddy harvesting to rice cooking. The environmental performance of rice production of these three methods are determined quantitatively and qualitatively and compared in order to identify the parboiling method having the least environmental burden and operations in the paddy parboiling processing line where specific impacts are high.

\section{Different parboiling methods in Sri Lanka}

Paddy parboiling process consists of three major steps, namely, soaking, steaming and drying which are carried out before the milling step. The main objective of the soaking process is to increase the moisture level of paddy to about $30 \%$. This ensures that sufficient water content is present for gelatinisation in the steaming step. Water absorption rate depends on water temperature and paddy variety. Various soaking methods are used in paddy parboiling in Sri Lanka. These methods are discussed in this section along with different paddy parboiling methods practised in Sri Lanka. Steaming is used to gelatinise the starch in paddy. Most of the biological activities are destroyed and enzymes present in the grain are destroyed or temporarily inactivated due to steaming process (Institute of Post Harvest Technology, 2007). The steaming methods used in paddy parboiling in Sri Lanka are also described in this section along with different paddy parboiling methods practiced. 
After steaming process, parboiled paddy needs to be dried until moisture level becomes $14 \%$ for safe storage and milling purpose. Sun drying is the most popular paddy drying method used in domestic and low capacity mills in Sri Lanka. It is usually cheaper than mechanical drying and drying is done by spreading paddy on the floor, up to one to three centimetres thick layer with the help of planks. These layers need to be continuously turned in order to avoid irregular drying and exposing the grain to unnecessary temperatures which make cracks in grains. The continuous-flow Louisiana State University (LSU) dryer type is the most common mechanical dryer used in Sri Lanka for drying paddy (Institute of Post Harvest Technology, 2007). The wet paddy enters the dryer at the top and flows continuously through the dryer while heated air is blown through the paddy from the bottom. During mechanical drying, the rate of moisture removal can be regulated and therefore plant operation becomes more uniform.

Four major parboiling methods practiced in Sri Lanka are discussed in following sections. A detailed description of these methods is also available in CEA (2001) and Environmental \& Management Lanka (Private) limited (1999).

\section{Traditional cold soaking method}

In traditional cold soaking method, paddy is soaked in a series of rectangular cement tanks containing water at ambient temperature. Soaking time varies from 24 hours (short paddy varieties) to 48 hours (long paddy varieties). The soaking water needs to be changed every 12 hours to reduce fermentation and other adverse effects. However, in most paddy mills the practice is to change soak water every 24 hours. Paddy is subjected to steaming in a separate circular metal tank which consists of a perforated metal plate at the bottom, inside the tank. Paddy is placed on this metal plate and steam is sent through the perforated plate from the bottom. Steam is produced by heating water placed under the plate. The heat for boiling water is supplied using a husk fired furnace located below the metal tank. After steaming paddy is sun dried.

\section{Traditional hot soaking method}

Traditional hot soaking method is carried out in a metal tank which has a perforated metal plate inside. In soaking step, the tank is filled with paddy on the metal plate and then soaking water is added to cover paddy. Water and paddy are heated using a furnace located below the tank. During soaking, water temperature is maintained at $60-70^{\circ} \mathrm{C}$ for three to four hours [Environmental \& Management Lanka (Private) limited, 1999]. The soaking time required depends on paddy variety and temperature. In steaming step, water level is reduced below the perforated plate in the same tank and heat is applied to produce steam by the husk fired furnace. The water is drained through a valve and the level in the tank is controlled manually. Finally, paddy is sun dried on a cement floor to reduce the moisture content to the required level for milling and storage.

\section{Semi- modern method}

Semi modern cold soaking method is the most common parboiling method used in Sri Lanka. In this method cement tanks with water at ambient temperature are used for the soaking process. Cold soaking is carried out for three to four days depending on the paddy variety. The soaking water is changed every 24 hours. After soaking, paddy load is transferred to small cylindrical iron kettles for the steaming process. Steam is produced in husk fired boilers and supplied to kettles. The paddy is steamed using a steam pipe placed inside the kettle centre. A commonly found kettle can hold about $370 \mathrm{~kg}$ of soaked paddy (Wimberly, 1983). According to the Institute of Post Harvest Technology (2007), $60 \mathrm{~kg}$ of $413.69 \mathrm{kPa}$ pressurised steam is required to steam one ton of paddy. Steaming duration required varies from 5 to 15 minutes (Kannan et al., 2015). Finally, paddy is subjected to sun drying.

\section{Modern method}

In this method water that is maintained at a temperature of $70{ }^{\circ} \mathrm{C}$ is used for soaking paddy in open kettles. The temperature in the kettle is maintained throughout the soaking operation by recirculating hot water. Soaking process is carried out for three to four hours as required depending on the paddy variety. According to studies carried out by the Institute of Post Harvest Technology (2007), $110 \mathrm{~kg}$ of $413.69 \mathrm{kPa}$ pressurised steam is required per one ton of paddy for hot soaking process. Steaming duration required varies from 10 to 20 minutes [Environmental \& Management Lanka (Private) limited, 1999]. After steaming, paddy is subjected to sun drying or mechanical drying.

\section{METHODOLOGY}

The environmnetal burdens of the life cycle of a product or process can be estimated using LCA methodology. This methodogy is considered as an effective tool for environmental performance analysis in the food 
processing industry (Roy et al., 2009a,b; Cellura et al., 2012). Therefore LCA approach is used in this work to compare environmnetal performance of alternate parboiled rice production processes. LCA methodology developed by the International Organization for Standardization (ISO) comprises four major steps, namely, goal and scope definition, life cycle inventory analysis, life cycle impact assessment and interpretation of the results (ISO, 2006). The Handbook on Life Cycle Asssessment published by Guinee et al. (2002) has presented the operational guide to the ISO standards for LCA. The International Reference Life Cycle Data System (ILCD) Handbook containing general guide for LCA provides a detailed technical guidance to the ISO 14040 and 14044:2006 standards on Life Cycle Assessment (European Commission, 2010). The guidance data and scientific background information on LCA methodology provided in these handbooks are used in the LCA study of this work.

\section{Assessment of Environmental Performance of Paddy Parboiling Process}

The environmental performance assessment includes definition of the goal and scope, analysis of the life cycle inventory, allocation criteria and assessment of the life cycle impact.

\section{Goal of the environmental assessment}

Goal of this study is to identify the paddy parboiling methodology having the least life cycle environmental burden and operations in the paddy parboiling processing line where specific impacts are high. Parboiled paddy production process starting from paddy harvesting step to rice cooking step are assessed for environmental performance. In this production process, three different methods of parboiling are assessed and compared. The methods include hot and cold soaking paddy parboil methods. The Institute of Post Harvest Technology is promoting modernisation of existing rice mills to produce better quality rice (Institute of Post Harvest Technology, 2018). Therefore, out of the hot soaking methods adopted for parboiling, the modern method is analysed considering two different parboiled paddy drying methods. In this work these two methods are named as modern method with mechanical drying (Method 1) and modern method with sun drying (Method 2). The semi modern method which is the most common method used in paddy parboiling with cold soaking and sun drying is considered as the third alternative (Method 3).

\section{Method 1}

Method 1 includes hot soaking, steaming and mechanical drying operations. Hot soaking is carried out by soaking the paddy in hot water at $70^{\circ} \mathrm{C}$ for four hours. Pressurised steam generated from paddy husk fired boilers is used in steaming process and also to maintain the temperature in hot water used for hot soaking process. Finally, paddy is sent through the mechanical dryer (Louisiana State University dryer) to reduce the moisture level.

\section{Method 2}

Method 2 includes paddy parboiling with hot soaking, steaming and sun drying operations. The hot soaking and steaming processes in this method are similar to those in Method 1. Paddy is sun dried after the steaming operation.

\section{Method 3}

Method 3 is similar to semi modern parboiling method which includes cold soaking, steaming and sun drying. Water at ambient temperature is used for cold soaking and soaking is carried out for 48 hours. Pressurised steam generated from paddy husk fired boilers is used for the steaming process. Finally, paddy is sun dried.

\section{Scope of the environmental performance assessment}

This LCA study presents estimation of environmental impacts involved in operations in the rice processing line including; paddy harvesting, threshing, winnowing, drying harvested paddy, washing, parboiling, milling and rice cooking by the consumer. The parboiling step involves paddy soaking, steaming and drying. The environmental impacts of each and every production step are determined to identify the steps in which the adverse impacts are concentrated. The influence of the environmental burdens of capital goods, that is the production of machinery, roads and buildings are excluded in this assessment by considering the very high throughput of work over machine's life (Roy et al., 2006; Blengini \& Busto, 2009). It is recognised that paddy and rice transportation and storage activities also contribute to environmental burdens. However, as data related to LCA on these steps are lacking, they are not included in the scope of this study. Studies on parboiling process in Sri Lanka have shown that most rice mills discharge effluent from parboiling process to the environment without treatment (Ariyarathna et al. 2007; Kannan 
et al., 2015). Therefore, end of the pipe pollution control measures such as wastewater treatment are not included in the scope of this work. Further, in the comparison of all three alternate paddy parboiling methods, the same qualities of paddy are considered. Therefore, it is assumed that there is no effect on the environmental performance due to the paddy variety used in its process. However, it is recognised that different qualities of different paddy varieties could result in varying environmental impacts.

\section{Functional unit}

The functional unit is taken as 'production of one ton of parboiled rice'. Parboiled rice is obtained by milling parboiled paddy. This rice is used in the cooking step. Therefore, all the impacts in this work are assessed based on one ton of parboiled rice which is produced and measured next to the parboiled paddy milling process.

\section{System boundaries}

Two cases are defined for the system boundary. In Case 1 , processes from harvesting of paddy to cooking of rice are included in the system boundary (Figure 1). These processes include harvesting, threshing, winnowing, drying harvested paddy, washing, parboiling (including soaking, steaming and drying), milling of parboiled paddy and cooking parboiled rice. Case 1 is analysed for three methods of paddy parboiling separately as shown in Figure 1. In this case, for all three alternative paddy parboiling methods which consist of steps: paddy soaking, steaming and drying, the environmental performances of all other rice processing steps (harvesting, threshing, winnowing, drying harvested paddy, washing, milling and cooking) are assumed the same. This system boundary captures many operations in the rice production line enabling identification of various operations that are

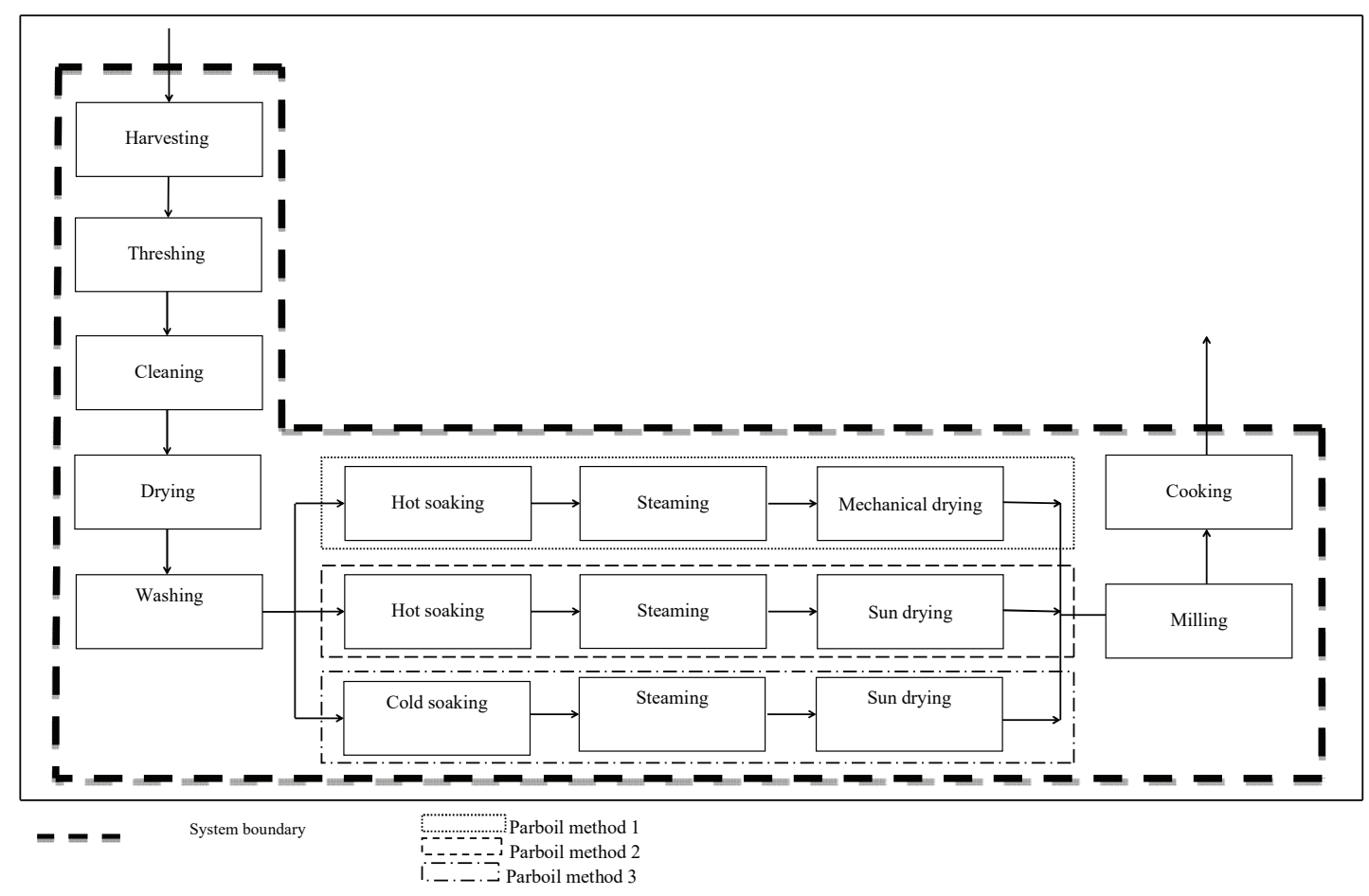

Figure 1: Process flow and system boundary for Case 1

involved with high environmental burdens. In Case 2, the system boundary includes only the parboiling process which has the three steps, soaking, steaming and drying operations (Figure 2). The system boundary shown in Figure 2 is considered as a separate case to facilitate comparison of the three paddy parboiling processes. 


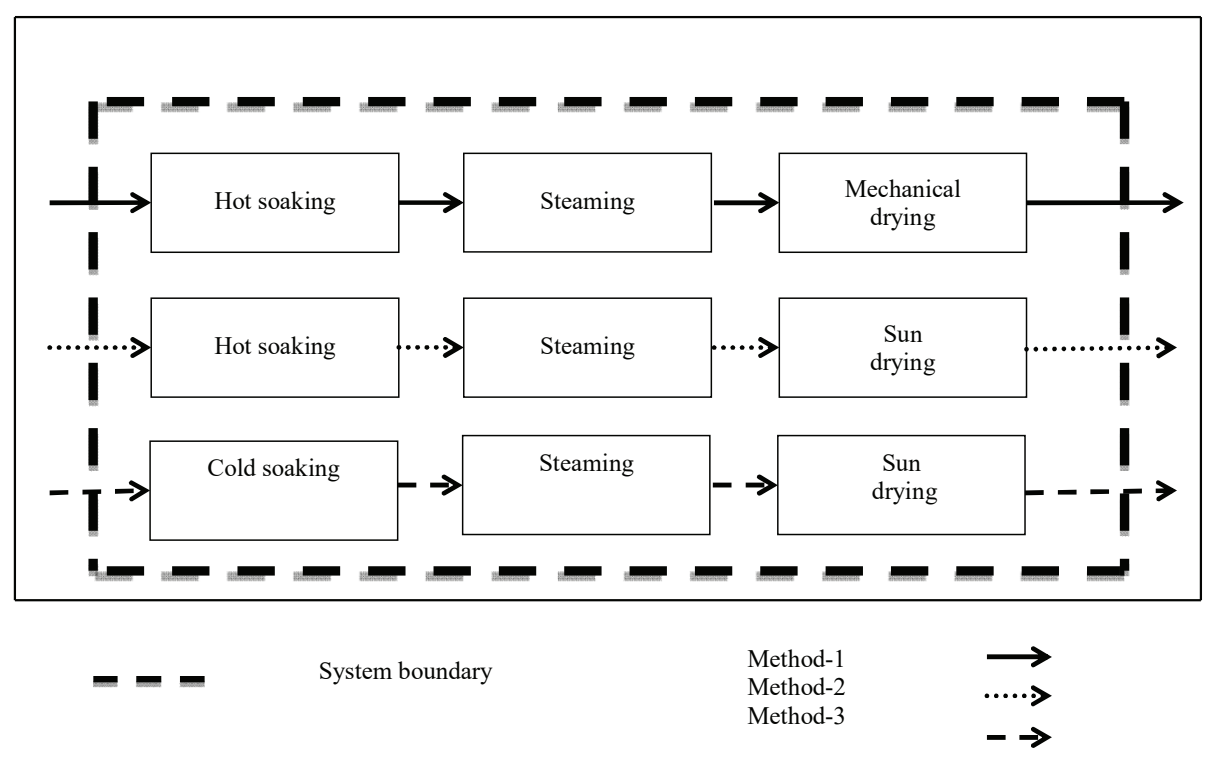

Figure 2: Process flow and system boundary for Case 2

\section{Life cycle inventory analysis (LCIA)}

In Life Cycle Inventory (LCI) analysis step, all the details of environmental inputs (material and energy) and outputs (water, air emissions, solid emissions, etc.) at each step are analysed. The analysis was carried out in a computer excel spread sheet with data from literature sources for material and energy balances. These data used in deriving inventories are elaborated in this section and in a latter section. More data associated with the calculation of this environmental inventories of parboiled rice production are available in Nadeeshani (2015). The environmental burdens estimated in steps from harvesting to rice cooking consider only the emissions directly occurring from the respective operation.

Harvesting is the first step in the process flow of the system considered in this work. Manual harvesting with sickles is considered in this work for the estimation of lifecycle inventory. However, it is recognised that according to the recent publication by the Department of Census and Statistics (2018) machine harvesting is being adopted by most of the farmers in Sri Lanka. Threshing is conducted by low capacity threshers which have a threshing rate of $400 \mathrm{~kg} / \mathrm{hr}$ with $99.9 \%$ efficiency and it is operated with about $3.7 \mathrm{~kW}$ electric motor (Palipane, 2003; Baruah et al., 2004). Weight ratio of grain to straw is considered as one (Wijesundara et al., 1990). Fan coupled with two-wheel tractor is used in winnowing which is the common practice in Sri Lanka. In this work, the low capacity thresher motor and winnowing fan motor are taken as operated by tractor engines. Therefore, the diesel consumption of the tractor engines for the two operations are considered separately to estimate the emissions. The emissions of diesel fuel combustion in Sri Lanka published by the Ministry of Environment (2011) are considered to estimate the emissions of diesel engines in both threshing and winnowing processes.

Threshed paddy is sun dried which is the most popular drying method. Wastage or losses of paddy occurs in sun drying operation due to rodents and birds feeding on paddy being dried, and adverse weather conditions. After drying and before soaking, paddy is washed. In this washing step, water requirement is taken as about 1.3 times the weight of paddy (Institute of Post Harvest Technology, 2007). Electric water pump is used to feed water and the used water is drained off by gravity.

Water requirement for hot soaking is about 1.3 times the weight of paddy and water temperature is maintained at $70^{\circ} \mathrm{C}$ for four hours (Institute of Post Harvest Technology, 2007). Soaking in the hot soaking process requires about $360 \mathrm{MJ}$ of energy per one ton of paddy (Wimberly, 1983). In cold soaking, water at room temperature is used and soaking is done for 48 hours. Water requirement for cold soaking is nearly 1.3 times the weight of paddy (Institute of Post Harvest Technology, 2007). The soak water is changed every 24 hours which is the general practice in Sri Lanka. Steaming is carried out in small cylindrical iron kettles. Energy requirement of steaming is $105 \mathrm{MJ}$ per one ton of paddy (Wimberly, 
1983). In Method 1, the Louisiana State University (LSU) dryer used with steam heat exchanger requires energy equal to $573 \mathrm{MJ}$ per one ton of paddy for drying (Wimberly, 1983). The diesel requirement for the blower electricity in this drying process is taken as $15.6 \mathrm{~g} /$ ton of paddy parboiled (Wimberly, 1983). Emission data for diesel used in electricity generation available in Ministry of Environment (2011) are considered in estimating the emission inventory. Modern type rice mill is the most common commercial mill type used in Sri Lanka for milling paddy. The data for this study on all the machineries and their power requirements of a modern type rice mill are taken from the work done by Palipane (2003). Percentage of husk, bran and rice products of milling paddy is taken as $22 \%, 7 \%$ and $71 \%$ respectively (Roy et al., 2006).

The wood fired semi-circular mud stove is used most popularly for cooking rice (Perera \& Sugathapala, 2002). It was assumed that rice needs to be washed twice before cooking as this is the general practice in Sri Lanka and in each wash the same amount of water is used as used in for cooking. Quantity of water required for cooking process is taken as equal to 2.75 times the weight of rice (Billiris et al., 2012).

Environmental burdens of electricity consumption in all the electric equipment in milling operations and water pumps which are used for soaking and cleaning processes are taken from the Ministry of Environment (2011). These burdens include GHG and other emissions resulting from diesel fuel burning in thermal power plants in Sri Lanka.

Husk fired boilers are used to fulfil the steam requirements in hot soaking, steaming and heat exchanger in mechanical drying processes. The average heat value of husk is $12.5 \mathrm{MJ} / \mathrm{kg}$ and the husk fired boiler efficiency is $50 \%$ (Wimberly, 1983). Emissions of rice husk burning mentioned in Chungsangunsit et al. (2009) are taken as the husk fired boiler emissions.

A paddy loss of $2 \%$ was considered in the material balance conducted to estimate each inventory associated with harvesting, threshing, parboiling process and milling steps (Institute of Post Harvest Technology, 2007). Similarly, losses in winnowing, $0.02 \%$ and that for sun drying harvested paddy, $0.03 \%$ are considered (Institute of Post Harvest Technology, 2007).

\section{Allocation of environmental burdens among rice products and by-products}

Rice production is a multifunctional process that generates marketable products and by-products, as well as residuals. They include refined rice, bran, broken grains, rice flour, husk and straw. Therefore, allocation of environmental impacts among all these products needs to be carried out. In this study, the allocation of burdens to the co-products was done based on their relative economic values as given in Table 1. A similar method has been adopted by Blengini and Busto (2009) in their study of LCA of rice production. Unit price of the co-products were taken from Sri Lanka market data (Wijesooriya \& Priyadarshana, 2013; www.alibaba. com). Products, by products and residues other than head rice, bran and husk are considered as solid waste that has no market value.

\section{Life cycle impact assessment}

The environmental burdens identified in the inventory analysis were further analysed by selecting their associated impact categories. Classification, characterisation and normalisation steps were then carried out.

Table 1: Impact allocation percentages in parboiled rice production

\begin{tabular}{lcccc}
\hline Product & $\begin{array}{c}\text { Unit } \\
\text { price* } \\
\text { (Rs.) }\end{array}$ & $\begin{array}{c}\text { Weight per one ton } \\
\text { of parboiled rice } \\
\text { production }\end{array}$ & Value (Rs.) & $\begin{array}{c}\text { Allocation } \\
\text { percentage }\end{array}$ \\
\hline Head rice & $88,000.00$ & 1.00 & $88,000.00$ & $94.75 \%$ \\
Bran & $24,000.00$ & 0.10 & $2,400.00$ & $2.58 \%$ \\
Paddy & $8,000.00$ & 0.31 & $2,480.00$ & $2.67 \%$ \\
husk & & & & \\
\hline
\end{tabular}

* Based on Sri Lanka market prices (Wijesooriya \& Priyadarshana, 2013; www. alibaba.com) 


\section{Selection of impact categories}

Based on the inventory analysis results (Table 3 and Table 4), impact categories of depletion of abiotic resources, climate change, human toxicity, photo-oxidant formation, acidification and eutrophication were selected for the LCA study of parboiled rice production. All above categories fall under the 'baseline impact category' of the categorisation proposed by Guinee et al. (2002).

\section{Classification}

In the classification step, environmental interventions which flow across the boundary between the product system and the environment were assigned to the selected impact categories (Guinée et al., 2002). Classification of environmental interventions determined by the inventory analysis to relevant selected six impact categories are shown in Figure 3. There are few environmental inventories identified in the inventory analysis which are not falling under any of the selected impact categories. These inventories were classified into separate impact

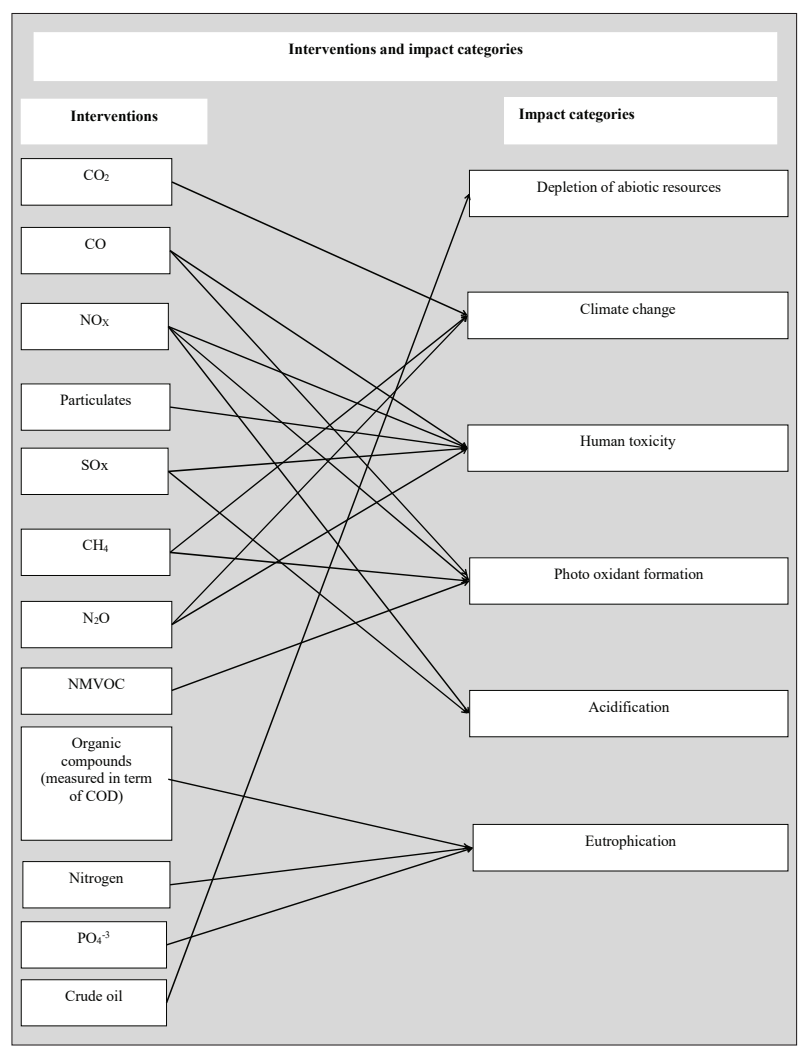

Figure 3: Classification of environmental interventions into selected impact categories
Table 2: Classification of environmental interventions which are not classified under the selected six impact categories

\begin{tabular}{ll}
\hline Interventions & $\begin{array}{l}\text { Relevant other } \\
\text { impacts }\end{array}$ \\
\hline $\begin{array}{l}\text { Paddy and rice losses } \\
\text { Paddy leaves and stems of leaves } \\
\text { Paddy straw (main stalk of paddy plant) } \\
\text { and chaff }\end{array}$ & Solid Waste \\
Paddy husk & \\
Bottom Ash & \\
Fly Ash & \\
Wastewater (From paddy washing process) & Wastewater \\
Wastewater (From cooking process) & (unknown \\
Fresh water & composition) \\
Packaging & Water consumption \\
\hline
\end{tabular}

categories, namely, solid waste, water consumption, packaging and wastewater with unknown characteristics and are shown in Table 2.

\section{Characterisation}

The baseline characterisation methods developed by Guinée et al. (2002) were considered in characterising all selected impact categories. As the composition of the non-methane volatile organic compounds (NMVOC) was not known, the determination of characterisation factors was not possible (Sheehan et al., 1998; Ministry of Environment, 2011). Therefore, the photo oxidant formation impact influenced by NMVOC emission was assumed to be equivalent to the photo oxidant formation impact of ethanol and calculated by using the characterisation factor of ethanol.

Qualitatively classified environmental interventions were quantified in characterisation step in terms of a common unit and then the calculated impacts of different types of environmental inventories were aggregated by summing up into a single score for each impact category. All the impact values calculated in the impact assessment before milling process were multiplied by impact allocation percentage of rice product which was equal to $94.75 \%$ in this work.

\section{Normalisation}

Although data related to Sri Lanka were not available to carry out this optional step of impact assessment, it was attempted using normalisation data related to 
the world. Goal of the normalisation is to establish a common reference to facilitate comparison of different environmental impacts and it helps to show to what extent an impact category has a significant contribution to the overall environmental problem. The normalisation factors with the annual per capita extent for world (1990) as mentioned in Guinee et al. (2002) were used in this LCA study. Although normalisation factors related to Sri Lanka for various impact categories were not yet available, the data related to climate change impact could be found. The total GHG emission of Sri Lanka in year 2000 had been $12,588.96 \times 10^{6} \mathrm{~kg} \mathrm{CO}_{2}$ eq. and per capita GHG emission of Sri Lanka in year 2000 had been 6.64 x $10^{2} \mathrm{~kg} \mathrm{CO}_{2}$ eq. capita ${ }^{-1}$ (Ministry of Environment, 2011).

\section{RESULTS AND DISCUSSION}

\section{Inventories of parboiled rice production}

Inventories of parboiling process for the three different parboiling methods mentioned in Case 1 and Case 2 for one ton of parboiled rice production are shown in Table 3 and Table 4, respectively. The wastewater quantity information for two categories, specified and unspecified was estimated in the lifecycle inventory analysis by carrying out water balances on each operation. Unspecified wastewater includes wastewater from paddy washing process carried out before soaking process and the wastewater from rice washing process carried out before cooking. This wastewater contains only sand, mud, solid particles such as chaff and no dissolved organic substances. Since its characteristics are unknown, in this work it is referred to as unspecified wastewater. The amount of wastewater (specified) shown for Method 1 and Method 2 in Table 3 and Table 4 includes wastewater from hot soaking operation. The wastewater (specified) shown in Table 3 and Table 4 for Method 3 is the wastewater generated from cold soaking operation. In Method 1 and Method 2 water input inventory shown in Table 3 includes water used for washing paddy before soaking, hot soaking and in cooking operations. The water input inventory for Method 1 and Method 2 in Table 4 is the water used in hot soaking operation and that for Method 3 is the water used in cold soaking operation. Paddy husk which is a solid waste in milling process is used in the parboiling process as biomass fuel to generate heat energy in husk fired boilers. Hot soaking, steaming and mechanical drying require this heat energy from the boiler. Husk consumption varies with the steam requirement in parboiling process. Method 1 of Case
2 with hot soaking, steaming and mechanical drying has the highest steam consumption. Method 2 needs a lower steam consumption compared to that in Method 1 because it practices sun drying instead of mechanical drying. Method 3 has the lowest energy consumption due to cold soaking and sun drying. Steam consumption for paddy steaming are similar in all three methods. Diesel is consumed in tractor engines that are used for driving the thresher and winnowing fan motors. Further, the diesel consumption for generating electricity in thermal power plants is also considered as part of diesel consumption in this lifecycle inventory analysis. In the system boundary of this work, electricity is used in pumping water for paddy washing and soaking operations, air blowing in mechanical drying and in milling operations. Diesel consumption shown for Method 2 and Method 3 in Table 4 is the diesel used for electricity generation for pumping water used in the paddy soaking operation. As water consumption in cold soaking operation is higher than that in hot soaking operation a higher diesel consumption is shown in Method 3 in Table 3 and Table 4. Method 1 shows the highest diesel consumption in Table 4, as in addition to water pumping, diesel is used for mechanical drying as well. Wood is used as an energy source for cooking process and wood input quantities for all three methods in Case 1 are also the same.

Output inventories of parboiled rice production are categorised under solid waste, air emissions, wastewater (specified), wastewater (unspecified), co products and packaging. Rice bran which is identified as a co-product is categorised in Table 3 separately. All the solid wastes produced other than paddy husk which is used as energy sources for parboiling process are similar for all three parboiling methods. The rice husk remained after milling operation in rice mills are dumped in open areas as solid waste. Some farmers burn the straw mainly when there is no other way of disposal. A small amount of rice straw is used as feed for cattle, and raw material for packaging, paper and paperboard manufacturing processes in Sri Lanka. Blengini and Busto (2009) excluded rice straw in their study of LCA and allocated no environmental burdens due to its insignificant market value. Although the solid outputs such as paddy straw, excess rice husk are not used in the boiler, fly ash and bottom ash have some useful applications, these have insignificant market values and therefore, in this work they were categorised under solid wastes.

The main $\mathrm{CH}_{4}$ contributor in Case 1 parboiled rice production is wood combustion in cooking step. 
Table 3: Inventories of one ton of parboiled rice production in Case 1

\begin{tabular}{|c|c|c|c|c|}
\hline \multirow{2}{*}{$\begin{array}{l}\text { Major inventories per one ton of } \\
\text { parboiled rice production }\end{array}$} & \multirow{2}{*}{ Unit } & \multicolumn{3}{|c|}{$\begin{array}{l}\text { Parboiling methods: steps from harvesting to } \\
\text { rice cooking }\end{array}$} \\
\hline & & Method 1 & Method 2 & Method 3 \\
\hline \multicolumn{5}{|l|}{ Inputs } \\
\hline Diesel & liters & 30.72 & 11.7 & 11.9 \\
\hline Water & $\mathrm{m}^{3}$ & 11.8 & 11.8 & 13.6 \\
\hline Wood & $\mathrm{kg}$ & 1,780 & 1,780 & 1,780 \\
\hline \multicolumn{5}{|l|}{ Outputs } \\
\hline \multicolumn{5}{|l|}{ Solid waste } \\
\hline Paddy and rice waste & $\mathrm{kg}$ & 107.6 & 107.6 & 107.6 \\
\hline Straw & $\mathrm{kg}$ & 1,484 & 1,484 & 1,484 \\
\hline Husk & $\mathrm{kg}$ & 37.61 & 188.1 & 267.3 \\
\hline Fly ash & $\mathrm{kg}$ & 37.5 & 15.4 & 3.8 \\
\hline Bottom ash from combustion & $\mathrm{kg}$ & 7.7 & 3.2 & 0.8 \\
\hline \multicolumn{5}{|l|}{ Co Product } \\
\hline Bran & $\mathrm{kg}$ & 93.4 & 93.4 & 93.4 \\
\hline \multicolumn{5}{|l|}{ Emissions to air } \\
\hline $\mathrm{CO}$ & $\mathrm{kg}$ & 135.22 & 134.06 & 133.46 \\
\hline $\mathrm{CH}_{4}$ & $\mathrm{~kg}$ & 15.47 & 15.47 & 15.47 \\
\hline NOx & $\mathrm{kg}$ & 2.77 & 2.47 & 2.38 \\
\hline $\mathrm{CO}_{2}$ & $\mathrm{~kg}$ & 2431.44 & 2155.11 & 2036.20 \\
\hline $\mathrm{SO}_{2}$ & $\mathrm{~kg}$ & 1.023 & 0.88 & 0.85 \\
\hline $\mathrm{N}_{2} \mathrm{O}$ & $\mathrm{kg}$ & $\mathrm{nv}$ & $\mathrm{nv}$ & $\mathrm{nv}$ \\
\hline NMVOC & $\mathrm{kg}$ & 0.013 & 0.01 & 0.01 \\
\hline TSP & $\mathrm{kg}$ & 15.7 & 15.6 & 15.6 \\
\hline \multicolumn{5}{|l|}{$\begin{array}{l}\text { Emissions to water with known } \\
\text { characteristics }\end{array}$} \\
\hline Wastewater (specified) & $\mathrm{m}^{3}$ & 1.60 & 1.60 & 3.40 \\
\hline $\mathrm{N}$ & $\mathrm{kg}$ & 0.02 & 0.02 & 0.04 \\
\hline $\mathrm{PO}_{4}^{-3}$ & $\mathrm{~kg}$ & 0.08 & 0.08 & 0.18 \\
\hline $\mathrm{COD}$ & $\mathrm{kg}$ & 9.61 & 9.61 & 17.33 \\
\hline \multicolumn{5}{|l|}{$\begin{array}{l}\text { Wastewater (characteristics } \\
\text { unknown) }\end{array}$} \\
\hline Waste water (Unspecified) & $\mathrm{m}^{3}$ & 7.30 & 7.30 & 7.30 \\
\hline Packaging - Polypropylene (PP) & $\mathrm{kg}$ & 6.28 & 6.28 & 6.28 \\
\hline
\end{tabular}

'nv'-value is negligible and therefore not shown

Diesel combustion is the main contributor of $\mathrm{CH}_{4}$ emission in parboiling processes of Case 2 and it is a negligible value compared to case 1 . The emission factors presented in Perera and Sugathapala (2002) for fuel wood fired semicircular mud stoves were used in $\mathrm{CH}_{4}$ inventory estimation. Husk fired boiler emissions 
Table 4: Inventories of parboiling processes of Case 2

\begin{tabular}{|c|c|c|c|c|}
\hline \multirow{3}{*}{$\begin{array}{l}\text { Major inventories per } \\
\text { functional unit }\end{array}$} & \multirow{3}{*}{ Unit } & \multicolumn{3}{|c|}{ Parboiling Methods } \\
\hline & & \multicolumn{3}{|c|}{ (soaking, steaming and drying) } \\
\hline & & Method 1 & Method 2 & Method 3 \\
\hline \multicolumn{5}{|l|}{ Inputs } \\
\hline Diesel & liters & 19.05 & 0.03 & 0.18 \\
\hline Water & $\mathrm{m}^{3}$ & 1.8 & 1.8 & 3.6 \\
\hline Rice Husk & $\mathrm{kg}$ & 256 & 105 & 26 \\
\hline \multicolumn{5}{|l|}{ Outputs } \\
\hline \multicolumn{5}{|l|}{ Solid waste } \\
\hline Paddy and rice waste & $\mathrm{kg}$ & 27.6 & 27.6 & 27.6 \\
\hline Fly ash & $\mathrm{kg}$ & 37.5 & 15.4 & 3.8 \\
\hline Bottom ash from combustion & $\mathrm{kg}$ & 7.7 & 3.2 & 0.8 \\
\hline \multicolumn{5}{|l|}{ Emissions to air } \\
\hline $\mathrm{CO}$ & $\mathrm{kg}$ & 1.969 & 0.81 & 0.20 \\
\hline NOx & $\mathrm{kg}$ & 0.435 & 0.12 & 0.03 \\
\hline $\mathrm{CO}_{2}$ & $\mathrm{~kg}$ & 435.5 & 159.18 & 40.27 \\
\hline $\mathrm{CH}_{4}$ & $\mathrm{~kg}$ & 0.001 & $\mathrm{nv}$ & nv \\
\hline $\mathrm{N}_{2} \mathrm{O}$ & $\mathrm{kg}$ & $\mathrm{nv}$ & $\mathrm{nv}$ & nv \\
\hline NMVOC & $\mathrm{kg}$ & 0.003 & $\mathrm{nv}$ & $\mathrm{nv}$ \\
\hline $\mathrm{SO}_{2}$ & $\mathrm{~kg}$ & 0.093 & & \\
\hline TSP & $\mathrm{kg}$ & 14.8 & 14.8 & 14.8 \\
\hline \multirow{2}{*}{\multicolumn{5}{|c|}{$\begin{array}{l}\text { Emission to water with } \\
\text { known characteristics }\end{array}$}} \\
\hline & & & & \\
\hline Waste water (specified) & $\mathrm{m}^{3}$ & 1.60 & 1.60 & 3.40 \\
\hline $\mathrm{N}$ & $\mathrm{kg}$ & 0.02 & 0.02 & 0.04 \\
\hline $\mathrm{PO}_{4}^{-3}$ & $\mathrm{~kg}$ & 0.08 & 0.08 & 0.18 \\
\hline COD & $\mathrm{kg}$ & 9.6 & 9.6 & 17.3 \\
\hline
\end{tabular}

'nv'-value is negligible and therefore not shown

and wastes are $\mathrm{CO}, \mathrm{CH}_{4}, \mathrm{NO}_{\mathrm{x}}, \mathrm{CO}_{2}, \mathrm{~N}_{2} \mathrm{O}$, NMVOC and TSP. These emissions vary according to the heat energy generation in the boiler. Method 1 has the highest energy consumption and it has resulted in the highest environmental emissions. Method 3 shows the lowest emissions which consumes the lowest heat energy quantity. Fly ash and bottom ash of husk fired boilers are considered as solid waste (Chungsangunsit et al., 2009) and are included under impact of solid wastes. This bottom ash inventories in Table 3 were estimated using the rice husk burning emission composition data given in Chungsangunsit et al. (2009). The emissions to air inventory shown in Table 4 (Case 2) includes husk combustion emissions and diesel combustion emissions from thermal power plants. Husk combustion energy is used in hot soaking, steaming and mechanical drying operations. Electricity is used in pumping water for paddy soaking operation and in air blower for mechanical drying. The husk combustion emissions shown in Table 4 were estimated using the rice husk burning emission composition data given in Chungsangunsit et al. (2009). The diesel fuel burning emission composition data in Ministry of Environment (2011) were used in estimating air emission inventory of diesel combustion. Quantity of $\mathrm{CO}_{2}$ emission of parboiled rice production in Case 1 has a very high value compared to other air emissions 
such as $\mathrm{CO}, \mathrm{CH}_{4}, \mathrm{NO}_{\mathrm{X}}, \mathrm{SO}_{2}, \mathrm{~N}_{2} \mathrm{O}$ and NMVOC. In Case 1 the major $\mathrm{CO}_{2}$ contributor is from fuel wood burning in cooking process. The major $\mathrm{CO}_{2}$ contributor of parboiling processes in Case 2 is paddy husk combustion. The $\mathrm{CO}_{2}$ emission in Method 2 shows a higher value than in Method 3 as husk combustion in it is higher. It is assumed that the $\mathrm{CO}_{2}$ emissions of rice husk burning quantified in the inventory analysis are re-absorbed by the biomass carbon cycle. Therefore, its environmental impacts are neglected assuming that the $\mathrm{CO}_{2}$ emissions during burning are balanced by consumption of $\mathrm{CO}_{2}$ in crop growth (Blengini \& Busto, 2009). Shackley et al. (2012) have also made a similar assumption equating the quantity of $\mathrm{CO}_{2}$ emission arising from the biotic or abiotic conversion of organic carbon to the quantity taken up by plant photosynthesis in subsequent growth cycles in their study of rice-husk gasification. The $\mathrm{CO}_{2}$ inventory of Method 1 is higher than that in Method 2 as $\mathrm{CO}_{2}$ emissions from diesel combustion for blower in mechanical drying is also included in Method 1. In estimating environmental impacts of $\mathrm{CO}, \mathrm{NO}_{2}$ and $\mathrm{SO}_{2}$, both inventories of husk and diesel combustion emissions are considered. For these air emissions, Method 3 shows low values as its husk combustion emissions are low.

The wastewater discharges from soaking process have known characteristics $\mathrm{N}, \mathrm{PO}_{4}^{-3}$ and $\mathrm{COD}$, and therefore considered as 'specified' in the inventory estimation. The water balance data along with parboil paddy wastewater characteristics presented in Karunaratne (2010) were used in estimating the paddy lifecycle inventory of cold soaking and hot soaking wastewater pollutant constituents of this work.

Characteristics of effluents of paddy washing water and rice washing water are assumed to have negligible environmental impacts. The data on characteristic values of COD, $\mathrm{N}$, and $\mathrm{PO}_{4}^{-3}$ of paddy soaked wastewater show higher values in cold soaked wastewater compared to wastewater from hot soaking method.

The quantities of packaging are similar in all three methods. The weight of a polypropylene bag used to pack one $\mathrm{kg}$ of parboiled rice available in the market is about $6.28 \mathrm{~g}$. Therefore, the calculated polypropylene bags requirement per one ton of parboiled rice is $6.28 \mathrm{~kg}$. Transportation of paddy and rice also gives rise to considerable burdens on the environment. The transportation distances vary according to the location of paddy fields, rice mills, markets and consumers. However, these environmental emissions were not considered in the impact assessment step because assessed data on average values for paddy and rice transportation related to Sri Lanka were not available.
According to the study done by Roy et al. (2007) the $\mathrm{CO}_{2}$ emissions of parboiled rice production using 'vessel' method and 'medium boiler' method were about $1310 \mathrm{~kg}$ and $1210 \mathrm{~kg}$ per one ton of parboiled rice, respectively. These results were similar to the results obtained in this work Case 1. The differences in results may be due to the differences of selected parboiling methods and the system boundaries. Some processes considered in the system boundary of this study such as threshing, winnowing, washing and drying had not been included in the system boundary of the study of Roy et al. (2007).

\section{Environmental impact assessment of parboiled rice production}

\section{Classification}

From the inventory analysis, the environmental interventions were identified and classified to selected impact categories as shown in Figure 3 and Table 2. Consumption of crude oil is classified as an impact falling under the depletion of abiotic resources. Although river water resource is categorised under abiotic resources, it is considered as a resource regenerated constantly (Guinee, et al., 2002). Air emissions can cause climate change, human toxicity, photo-oxidant formation and acidification impacts. Pollutants in wastewater such as organic matters, $\mathrm{N}$ and $\mathrm{P}$ cause eutrophication. Therefore, during the classification step of lifecycle impact assessment, organic matters, $\mathrm{N}$ and $\mathrm{P}$ are classified to eutrophication impact category. Allocation of environmental interventions among products and co products are done based on allocation fractions shown in Table 1.

\section{Characterisation of impact categories}

Characterised values of environmental impacts classified under the selected impact categories of parboiled rice production are shown in Table 5. Other environmental burdens which are not classified under the selected impact categories are shown in Table 6.

In this work harvesting is considered as performed manually. Therefore, no significant impact on environment is observed. Although sun drying produces particulate solid waste, as paddy is turned several times during drying, the environmental impact of this process is also considered as insignificant. Depletion of abiotic resources caused by diesel consumption is highest in mechanical drying process which requires the highest quantity of electric energy which is generated using diesel. Milling process requires the next highest quantity of electricity generated using diesel. Threshing, winnowing, paddy 
washing, cold soaking and hot soaking also contribute to the impact of abiotic resources depletion as diesel is consumed in these operations. Climate change impact is observed highest in the cooking process. The climate change effect of $\mathrm{CO}_{2}$ emission from burning biomass (husk and wood) is excluded by considering the assumption that $\mathrm{CO}_{2}$ emissions of burning biomass are reabsorbed by the biomass carbon cycle (Blengini \& Busto, 2009). Therefore, for the calculation of climate change effect of cooking, only the effect caused by $\mathrm{CH} 4$ emission from fuel wood burning was considered. Apart from cooking, other processes such as threshing, winnowing, paddy washing, cold soaking, hot soaking, mechanical drying and milling also contribute to climate change impact. Cooking process shows the highest impact on climate change, human toxicity, photo oxidant formation and acidification. Threshing, winnowing, hot soaking, steaming, mechanical drying and milling processes contribute to photo oxidant formation. Acidification impact is caused by threshing, winnowing, washing, cold soaking, hot soaking, steaming, mechanical drying, milling and cooking processes. Eutrophication impact is caused by emissions from cold soaking and hot soaking processes.

Table 5: Characterisation of impact categories of one ton of parboiled rice production

\begin{tabular}{|c|c|c|c|c|c|c|c|c|c|c|c|c|c|}
\hline $\begin{array}{l}\text { Impact } \\
\text { category }\end{array}$ & Unit & 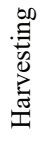 & 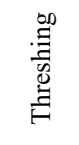 & 泀 & 泀 & $\begin{array}{l}\stackrel{\infty}{0} \\
\frac{1}{5} \\
\frac{\pi}{3}\end{array}$ & $\underset{0}{0} \cdot \frac{b}{0}$ & 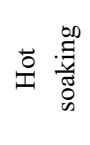 & 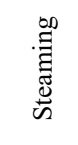 & 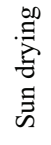 & 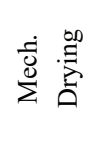 & $\stackrel{\infty}{\stackrel{\Xi}{\Xi}}$ & $\frac{0}{\ddot{\Xi}}$ \\
\hline $\begin{array}{l}\text { Depletion } \\
\text { of abiotic } \\
\text { resources }\end{array}$ & $\begin{array}{c}\text { kg antimony } \\
\text { eq. }\end{array}$ & - & 0.023 & 0.004 & - & 0.001 & 0.003 & nv & - & - & 0.297 & 0.167 & - \\
\hline $\begin{array}{l}\text { Climate } \\
\text { change }\end{array}$ & $\mathrm{kg} \mathrm{CO}_{2}$ eq. & - & 3.57 & 0.57 & - & 0.24 & 0.48 & 0.072 & nv & - & 46.99 & 27 & 324 \\
\hline $\begin{array}{l}\text { Human } \\
\text { toxicity }\end{array}$ & $\begin{array}{c}\text { kg 1,4- DCB } \\
\text { eq. }\end{array}$ & - & 0.047 & 0.008 & - & 0.001 & 0.002 & 0.120 & 0.040 & - & 0.391 & 0.093 & 15.58 \\
\hline $\begin{array}{l}\text { Photo oxidant } \\
\text { formation }\end{array}$ & $\mathrm{kg} \mathrm{C}_{2} \mathrm{H}_{4}$ eq. & - & 0.012 & 0.002 & - & nv & nv & 0.019 & 0.006 & - & 0.042 & 0.004 & 3.75 \\
\hline Acidification & $\mathrm{kg} \mathrm{SO}_{2}$ eq. & - & 0.028 & 0.004 & - & 0.001 & 0.002 & 0.080 & 0.026 & - & 0.322 & 0.098 & 2.05 \\
\hline Eutrophication & $\mathrm{kg} \mathrm{PO}_{4}^{-3}$ eq. & - & - & & - & - & 0.576 & 0.3 & $\mathrm{nv}$ & - & - & - & - \\
\hline
\end{tabular}

'nv'-value is negligible and therefore not shown

Table 6: Other environmental burdens of one ton of parboiled rice production

\begin{tabular}{|c|c|c|c|c|c|c|c|c|c|c|c|c|c|}
\hline $\begin{array}{l}\text { Impact } \\
\text { category }\end{array}$ & Unit & 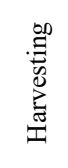 & 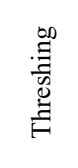 & 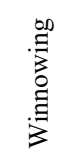 & 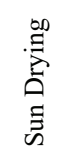 & 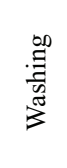 & 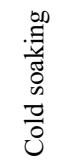 & 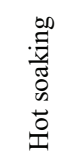 & 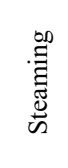 & 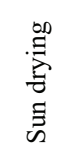 & 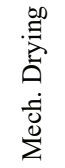 & $\stackrel{\stackrel{0}{\Xi}}{\stackrel{\Xi}{\Xi}}$ & 道 \\
\hline Solid waste & $\mathrm{kg}$ & 30.3 & 1,514 & 0.29 & 0.41 & - & - & 14.03 & 4.65 & 27.6 & 54.3 & 406.3 & - \\
\hline $\begin{array}{l}\text { Waste } \\
\text { water * }\end{array}$ & Tons & - & - & - & - & 1.79 & - & - & - & - & - & - & 5.50 \\
\hline $\begin{array}{l}\text { Water } \\
\text { consumption }\end{array}$ & $\mathrm{m}^{3}$ & - & - & - & - & 1.79 & 3.59 & 1.79 & - & - & - & - & 8.25 \\
\hline
\end{tabular}

*Wastewater with unknown composition 
Solid waste of parboiled rice production mainly comprised biomass of waste paddy and rice, paddy husk and paddy straw, fly ash and bottom ash. These solid wastes are recognised as non-toxic. The highest weight of solid waste is observed in threshing process where rice straw is the major waste. Winnowing is carried out to remove impurities such as weeds, half-filled grain, dust, chaff and straw. The solid waste in this process is assumed as $0.02 \%$. Sun drying of threshed paddy produces solid wastes due to rodents and birds and undesirable weather conditions. This quantity is taken as $0.03 \%$ of the paddy production which is lost during sun drying operation (Institute of Post-Harvest Technology, 2007). The total paddy loss in parboiling process is about 2\% (Institute of Post Harvest Technology, 2007). This loss is taken as part of paddy waste and considered at the end of the parboiling process, that is at drying step. Therefore, the solid waste in parboiled paddy drying operation in Table 6 shows a higher quantity compared to solid waste associated with sun drying of threshed paddy. Apart from these paddy wastes, bottom ash and fly ash from husk combustion used in generation of steam for mechanical dryer with steam heat exchanger are also considered as part of solid waste. Therefore, solid waste quantity in mechanical drying of parboiled paddy is higher than that of sun drying. According to Billiris et al. (2012), to obtain cooked rice with moisture content about $72 \%$, a water to rice ratio of 2.75 needs to be used for parboiled rice. Further, rice needs to be washed and cleaned before being cooked. In the lifecycle inventory estimation, it was considered that rice is washed twice using the same quantity of water that is consumed for cooking process. Therefore, highest water requirement is observed in the cooking process. Other than in cooking process, water is required in paddy washing and soaking processes.

Table 7: Characterised impacts of one ton of parboiled rice production (Case 1)

\begin{tabular}{lcccc}
\hline Impact categories & Method 1 & Method 2 & Method 3 & Units \\
\hline Depletion of abiotic resources & 0.492 & 0.195 & 0.197 & $\mathrm{~kg}$ antimony eq. \\
Climate change & 403.3 & 356.31 & 356.72 & $\mathrm{~kg} \mathrm{CO}_{2}$ eq. \\
Human toxicity & 16.28 & 15.896 & 15.777 & $\mathrm{~kg} \mathrm{1,4-} \mathrm{DCB} \mathrm{eq.}$ \\
Photo oxidant formation & 3.837 & 3.795 & 3.776 & $\mathrm{~kg} \mathrm{C}_{2} \mathrm{H}_{4}$ eq. \\
Acidification & 2.61 & 2.289 & 2.211 & $\mathrm{~kg} \mathrm{SO}_{2}$ eq. \\
Eutrophication & 0.299 & 0.299 & 0.576 & $\mathrm{~kg} \mathrm{PO}_{4}^{-3}$ eq. \\
\hline
\end{tabular}

Table 8: Other environmental burdens of one ton of parboiled rice production (Case 1) which are not classified under selected impact categories

\begin{tabular}{lcccc}
\hline Inventories & Method 1 & Method 2 & Method 3 & Units \\
\hline Solid waste & 1,768 & 1,892 & 1,957 & $\mathrm{~kg}$ \\
$\begin{array}{l}\text { Waste water (unknown } \\
\text { composition) }\end{array}$ & 7.29 & 7.29 & 7.29 & $\mathrm{~m}^{3}$ \\
$\begin{array}{l}\text { Water consumption } \\
\text { Packaging (pp) }\end{array}$ & 11.84 & 11.84 & 13.63 & $\mathrm{~m}^{3}$ \\
\hline
\end{tabular}

Summary of the characterisation of Case 1 are shown in the Tables 7 and 8 and the same for Case 2 are shown in the Tables 9 and 10. The abiotic resource depletion is highest in Method 1 as diesel consumption for electricity generation is highest in Method 1 due to its high diesel requirement for mechanical drying. As the diesel consumption for electricity generation is high in Method 3 due to higher water pumping requirement in cold soaking operation, the abiotic resources depletion impact is also higher compared to Method 2 as shown in Table 7. Table 8 shows a higher solid waste burden in Method 3. Part of this solid waste burden is contributed by the husk generated in milling process. A fraction of husk generated in milling process is consumed in the boiler for steam generation and the remaining husk contributes to the solid waste quantity shown in Table 8. As the husk consumption in boiler is low in Method 3 where cold soaking and sun drying are done, a high husk quantity is remained contributing to solid waste quantity. Therefore, the solid waste burden in Method 3 is high. 
Table 9: Environmental impacts of parboiling processes (Case 2) per functional unit

\begin{tabular}{lcccc}
\hline Impact categories & Method 1 & Method 2 & Method 3 & Units \\
\hline Depletion of abiotic resources & 0.297 & $\mathrm{nv}$ & 0.003 & $\mathrm{~kg}$ antimony eq. \\
Climate change & 47.06 & 0.072 & 0.481 & $\mathrm{~kg} \mathrm{CO}_{2}$ eq. \\
Human toxicity & 0.552 & 0.160 & 0.041 & $\mathrm{~kg} \mathrm{1,4-} \mathrm{DCB} \mathrm{eq.}$ \\
Photo oxidant formation & 0.067 & 0.025 & 0.006 & $\mathrm{~kg} \mathrm{C}_{2} \mathrm{H}_{4}$ eq. \\
Acidification & 0.430 & 0.106 & 0.028 & $\mathrm{~kg} \mathrm{SO}_{2}$ eq. \\
Eutrophication & 0.299 & 0.299 & 0.576 & $\mathrm{~kg} \mathrm{PO}_{4}^{-3}$ eq. \\
\hline
\end{tabular}

'nv'-value is negligible and therefore not shown

Table 10: Other environmental burdens of parboiling processes (Case 2) per functional unit which are not classified under selected impact categories

\begin{tabular}{lcccc}
\hline Inventories & Method 1 & Method 2 & Method 3 & Units \\
\hline Solid waste & 72.97 & 46.31 & 32.28 & $\mathrm{~kg}$ \\
Water consumption & 1.79 & 1.79 & 3.59 & $\mathrm{~m}^{3}$ \\
\hline
\end{tabular}

In Case 2, human toxicity, photo oxidant formation and acidification impacts are higher in Method 1. This is due to the high energy consumption in hot soaking and mechanical drying. The GHG emissions from diesel combustion contribute to climate change impact shown in Tables 7 and 9. As explained earlier the $\mathrm{CO}_{2}$ emissions of rice husk and fuel wood burning are assumed to be re-absorbed by the biomass carbon cycle and hence there is no contribution to climate change impact. As diesel consumption is high in Method 3 where water pumping requirement is higher for paddy cold soaking compared to Method 2, a higher climate change impact is observed. The highest climate change impact is observed in Method 1 where higher emissions from diesel consumption are observed due to generation of electricity for the blower used in mechanical drying process. Eutrophication impact is higher in Method 3 due to higher $\mathrm{P}$ and $\mathrm{N}$ content in wastewater resulting from cold soaking.

The solid waste environmental burden resulting from parboiling operations, namely, paddy soaking, steaming and drying are shown in Table 10. Solid wastes generated in each of the above operations are shown in Table 6. Solid wastes are not observed in cold soaking operation. However, solid wastes are observed in hot soaking and steaming which include fly ash and bottom ash from husk combustion. In drying operation which is the last step in the parboiling process, a $2 \%$ paddy solid wastes or losses are included as explained earlier. Solid wastes in mechanical drying operation include fly ash and bottom ash from husk combustion apart from paddy solid waste. Therefore, as shown in Table 10 Method 1 has the highest solid wastes which are contributed by hot soaking, steaming and mechanical drying operations. Method 3 has the lowest quantity of solid wastes which are contributed by steaming and sun drying operations.

When comparing the three methods, Method 1 shows the highest impact for depletion of abiotic resources, climate change, human toxicity, photo oxidant formation and acidification. Method 3 shows the highest impact for eutrophication. Comparison of methods 1 and 2 shows that Method 2 which has hot soaking and sun drying operations is having a better environmental performance. Same performance is observed in Case 2 where only parboiling operations are included in the system.

\section{Normalisation of environmental impacts}

Normalised results using normalisation factors related to the world for environmental impacts of parboiled rice production per functional unit for Case 1 are given in Figure 4.

According to results in Figure 4, the photo oxidant formation impact shows the highest impact on environment. Climate change and acidification also show a contribution to the impact on the environment. Normalised values of human toxicity give a negligible impact compared to other impacts. Although human toxicity and climate change show high impact values after characterisation, those have high normalisation factors 
compared to other impacts and therefore normalised values shown in Figure 4 are smaller. All environmental impacts other than eutrophication show very little variation among the three parboiling methods mentioned in Case 1. The reason for this result is that there are many steps such as harvesting, threshing, winnowing, washing, milling and cooking which are common to the three rice processing methods and only the parboiling process steps are varying.

Figure 5 shows the variation of normalised results based on world normalisation factors of impact categories among the parboiling methods in Case 2. According to the normalised results for Case 2, a high

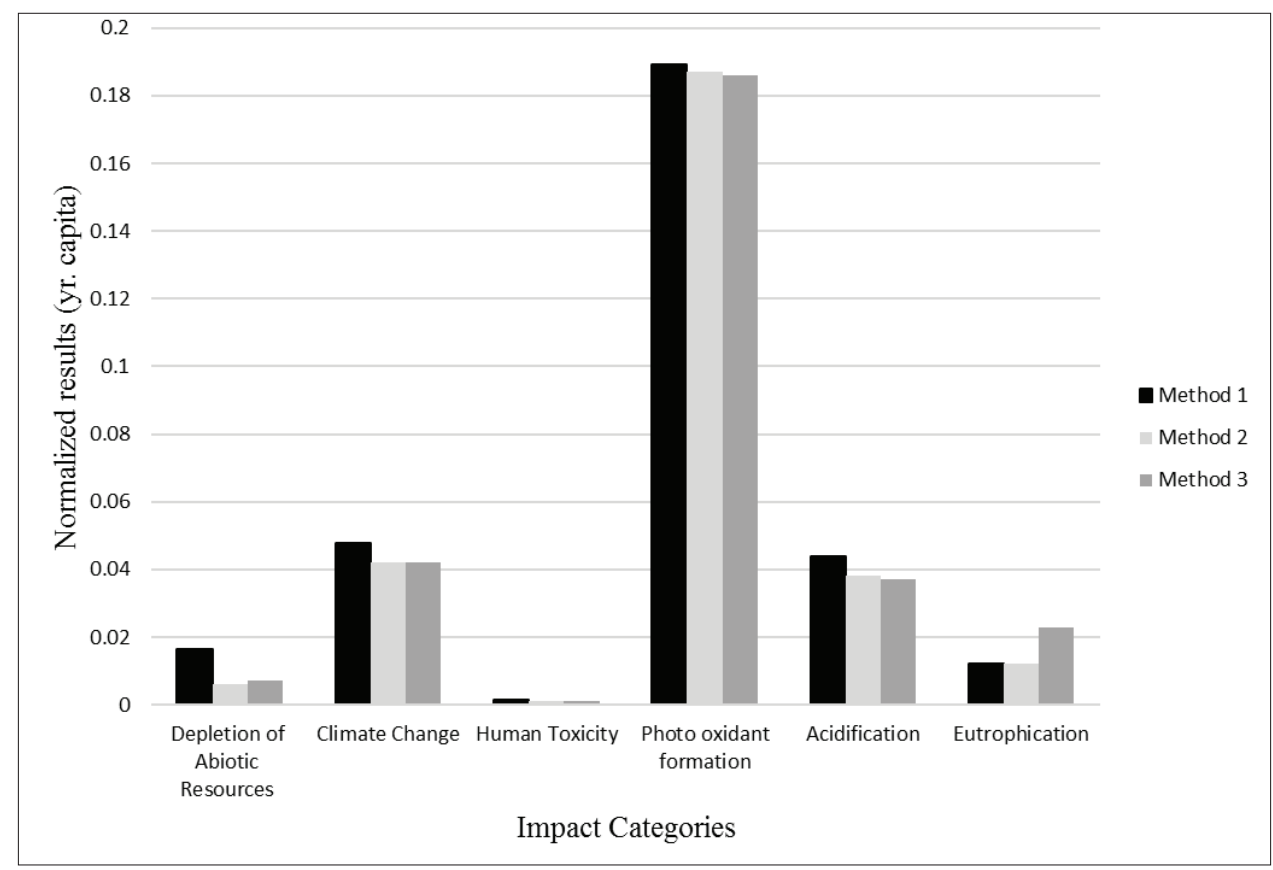

Figure 4: Normalised results of parboiled rice production in Case 1 per functional unit (annual per capita extent for world)

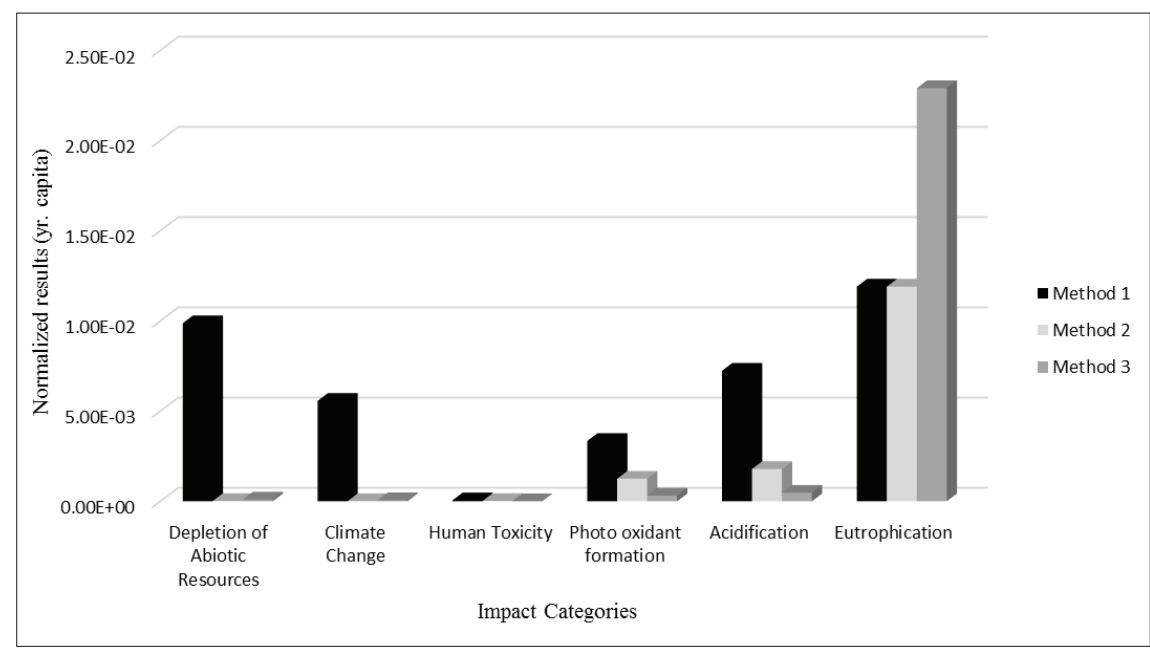

Figure 5: Normalised results of parboiling processes in Case 2 (annual per capita extent for world) 
eutrophication impact is shown for all three parboiling methods compared to other impacts. The depletion of abiotic resources, climate change, human toxicity, photo oxidant formation and acidification impacts are highest in Method 1.

Human toxicity and depletion of abiotic resources show low impacts in all three methods in Case 1. Therefore, in order to select a method with lower environmental impacts, the rest of the impacts are considered. Climate change, acidification and photo oxidant formation impacts are highest in Method 1, and Method 3 is having the highest eutrophication impact. Therefore, according to normalised results in Case 2, Method 2 shows a better environmental performance. However, with respect to human toxicity, acidification and photo oxidant formation impacts, cold soaking parboiling method shows better environmental performance.

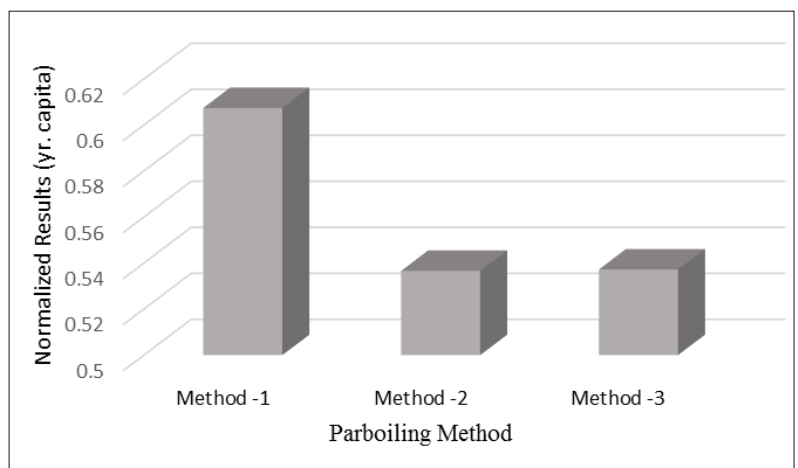

Figure 6: Normalised results of climate change impact of Case 1 per functional unit (normalisation factor is based on Sri Lanka)

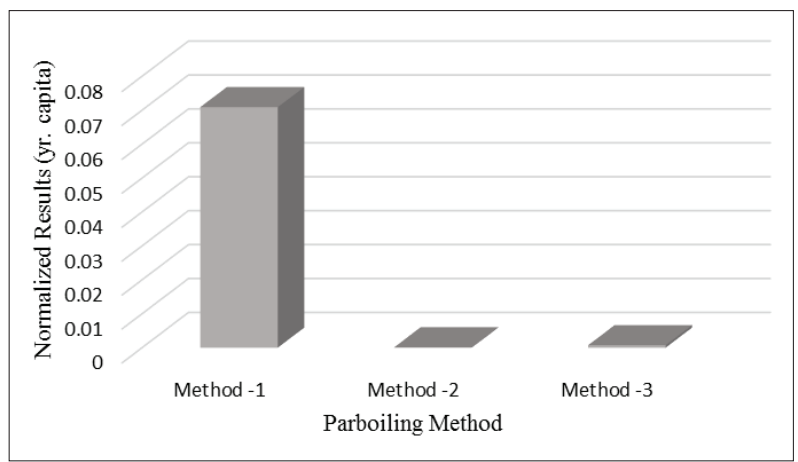

Figure 7: Normalised results of climate change impact of Case 2 per functional unit (normalisation factor is based on Sri Lanka)
The normalised results using normalisation factors based on Sri Lanka for climate change impact for Case 1 and Case 2 are shown in Figure 6 and Figure 7, respectively. The difference in magnitude of normalised results of the world and Sri Lanka is due to the low value of the normalisation factor of climate change impact in Sri Lanka. The emissions of the world GHG are very much higher compared to the GHG emissions in Sri Lanka.

\section{CONCLUSION}

In this study, environmental impacts of three parboiled rice production methods adopted in Sri Lanka were compared. To determine the environmental burdens associated with the production process, life cycle assessment methodology was applied. Environmental burdens of rice production vary depending on the method of production employed.

Based on inventory analysis and characterised impact category results, depletion of abiotic resources is higher in Method 1 where blower in mechanical drying required more diesel fuel. Eutrophication impact is higher in Method 3 where cold soaking of paddy is done which results in wastewater containing higher $\mathrm{P}$ and $\mathrm{N}$ contents. Parboiling step is the only step in the parboiled paddy production process that contributed to eutrophication impact.

The environmental impact assessment considering the life cycle of parboiled paddy production from harvesting step to rice cooking step showed main environmental impacts in climate change, eutrophication, acidification, depletion of abiotic resources, human toxicity and photo oxidant formation categories. Rice cooking operation contributes largely to all impacts except depletion of abiotic resources. Harvesting and sun drying operations have the least environmental burdens. With respect to climate change, eutrophication and depletion of abiotic resources, hot soaking parboiling method with sun drying has a better environmental performance. Findings indicate that acidification, human toxicity and photo oxidant formation impacts are least in cold soaking parboiling method.

The parboiling process consumes energy and materials and causes environmental impacts. When the energy consumptions of processes are high, the environmental emissions and related environmental damages are also high. Further investigations could be done to explore operations that might save energy. Promoting sun drying and saving fossil fuel usage are other options that might reduce environmental burdens. 


\section{Acknowledgement}

Authors gratefully acknowledge the financial support provided by the University of Moratuwa Senate Research Grant Number SRC/LT/2012/09.

\section{REFERENCES}

Ariyarathna S.M.W.T.P.K., Kalpage C.S. \& Shanthini R. (2007). Design of paddy husk charcoal adsorption unit for the treatment of parboiled rice processing wastewater, Proceedings of the Peradeniya University Research Sessions 12: 199-201.

Ariyarathna S.M.W.T.P.K., Siriwardhana H.P.D.S.N. \& Danthurebandara M. (2016). Life cycle assessment of rice processing in Sri Lanka: modern and conventional processing, Proceedings of the Moratuwa Engineering Research Conference (MERCon) 2016, 5-6 April. DOI: https://doi.org/10.1109/MERCon.2016.7480157

Baruah D.C., Das P.K. \& Dutta P.K. (2004). Present status and future demand for energy for bullock-operated farms in Assam (India). Applied Energy 79(2): 145-157. DOI: https://doi.org/10.1016/j.apenergy.2003.12.014

Billiris M.A., Siebenmorgen T.J. \& Wang Y.-J. (2012). Rice degree of milling effects on hydration, texture, sensory and energy characteristics. Part 2. Cooking using fixed, water-to-rice ratios. Journal of Food Engineering 113(4): 589-597.

DOI: https://doi.org/10.1016/j.jfoodeng.2012.07.006

Blengini G.A. \& Busto M. (2009). The life cycle of rice: LCA of alternative agri-food chain management systems in Vercelli (Italy). Journal of Environmental Management 90(3): 1512-1522.

DOI: https://doi.org/10.1016/j.jenvman.2008.10.006

Cellura M., Ardente F. \& Longo S. (2012). From the LCA of food products to the environmental assessment of protected crops districts: A case-study in the south of Italy. Journal of Environmental Management 93(1): 194-208.

Central Environmental Authority (CEA) (2001). Pollution Control Guidelines (for small scale industries), No.1 Paddy Mills. Central Environmental Authority and Ministry of Forestry and Environment, Sri Lanka. DOI: https://doi.org/10.1016/j.jenvman.2011.08.019

Chang N., Qi C., Islam K. \& Hossain F. (2012). Comparisons between global warming potential and cost-benefit criteria for optimal planning of a municipal solid waste management system. Journal of Cleaner Production 20(1): 1-13. DOI: https://doi.org/10.1016/j.jclepro.2011.08.017

Cherubini F. (2010). GHG balances of bioenergy systems e overview of key steps in the production chain and methodological concerns. Renewable Energy 35(7): 15651573.

DOI: https://doi.org/10.1016/j.renene.2009.11.035

Chungsangunsit T., Gheewala S.H. \& Patumsawad S. (2009). Emission assessment of rice husk combustion for power production. World Academy of Science, Engineering and Technology 3(5): 625-630.
Department of Census and Statistics (2018). Paddy Statistics 2017/2018 Maha Season, Department of Census and Statistics, Battaramulla.

Environmental \& Management Lanka (Private) limited (1999). Development of a Low Cost Technology for the Treatment of Rice Mill Effluents. Research project in association with the Department of Chemical Engineering, University of Moratuwa.

European Commission (2010). European CommissionJoint Research Centre-Institute for Environment and Sustainability: International Reference Life Cycle Data System (ILCD) Handbook-General guide for Life Cycle Assessment - Detailed guidance. EUR 24708 EN. Publications Office of the European Union.

Guinée J.B et al. (2002). Handbook on Life Cycle AsssessmentOperational Guide to the ISO- Standards. Kluwer Academic Publishers, New York, USA.

Institute of Post Harvest Technology (2007). Parboiling of Paddy. Research and Development Centre, Institute of Post Harvest Technology Anuradhapura, Sri Lanka.

Institute of Postharvest Technology (2018). Improvement of the Quality of Locally Produced Rice to International Standards. Available at http://ipht.lk/Main\%20Activities/ Rice\%20mills.html, accessed 01 June 2018.

International Organization for Standards (ISO) (2006), ISO 14040:2006, Environmental Management - Life Cycle Assessment: Principles and Framework, Available at https://www.iso.org/standard/37456.html, accessed 30 May 2018.

Kamalakkannan S. \& Kulatunga A.K. (2018). Life cycle assessment of rice processing, International Conference on Industrial Engineering and Operations Management, pp. 3417-3424.

Kannan N., Dharmasena D.A.N. \& Mannapperuma J.D. (2015). Investigation of a resource-efficient technique for paddy parboiling industry. World Applied Sciences Journal 33(1): 51-62.

Karunaratne H.W.G.I. (2010). Removal of pollutants in parboiled paddy wastewater. M.Sc. thesis, University of Moratuwa.

Karunaratne H.W.G.I. \& Gunasekera M.Y. (2009). Removal of pollutants in soak wastewater resulting from parboiling of paddy, ENGINEER XXXXII(4): 112-121.

DOI: https://doi.org/10.4038/engineer.v42i4.7040

Kwofie E.M. \& Ngadi M. (2017). A comparative lifecycle assessment of rural parboiling system and an integrated steaming and drying system fired with rice husk. Journal of Cleaner Production 140(2): 622-630.

DOI: https://doi.org/10.1016/j.jclepro.2016.06.008

Miah M.A.K., Haque A., Douglass M.P. \& Clarke B. (2002). Parboiling of rice. Part I:Effect of hot soaking time on quality of milled rice. International Journal of Food Science and Technology 37: 527-537.

DOI: https://doi.org/10.1046/j.1365-2621.2002.00610.x

Ministry of Environment (2011). Sri Lanka's Second National Communication on Climate Change. Climate Change Secretariat, Ministry of Environment, Sri Lanka.

Mohammadi A., Rafiee S., Jafari A., Keyhani A., Dalgaard T., 
Knudsen M.T., Nguyen T.L.T., Borek R. \& Hermansen J.E. (2015). Joint life cycle assessment and data envelopment analysis for the benchmarking of environmental impacts in rice paddy production. Journal of Cleaner Production 106: 521-532.

DOI: https://doi.org/10.1016/j.jclepro.2014.05.008

Nadeeshani E. (2015). Environmental Assessment of Parboiled Paddy Production by Life Cycle Assessment. M.Sc. thesis, University of Moratuwa, Sri Lanka.

Palipane K. (2003). Milling and quality improvement in rice. Rice Congress. Sri Lanka.

Perera K.K.C.K. \& Sugathapala A.G.T. (2002). Fuelwood Fired Cookstoves in Sri Lanka and related issues. Energy for Sustainable Development 6(1): 85-94. DOI: https://doi.org/10.1016/S0973-0826(08)60302-6

Roy P., Ijiri T., Nei D., Orikasa T., Okadome H., Nakamura N. \& Shiina, T. (2009a). Life cycle inventory (LCI) of different forms of rice consumed in households in Japan. Journal of Food Engineering 91: 49-55. DOI: https://doi.org/10.1016/j.jfoodeng.2008.08.005

Roy P., Nei D., Orikasa T., Xu Q., Okadome H., Nakamura N. \& Shiina T. (2009b). A review of life cycle assessment (LCA) on some food products. Journal of Food Engineering 90: $1-10$. DOI: https://doi.org/10.1016/j.jfoodeng.2008.06.016

Roy P., Shimizu N., Okadome H., Shiina T. \& Kimura T. (2007). Life cycle of rice: Challenges and choices for Bangladesh. Journal of Food Engineering 79(4): 1250-1255. DOI: https://doi.org/10.1016/j.jfoodeng.2006.04.017

Roy P., Shimizu N., Shiina T. \& Kimura T. (2006). Energy consumption and cost analysis of local parboiling process. Journal of Food Engineering. 76(4): 646-655. DOI: https://doi.org/10.1016/j.jfoodeng.2005.06.034
Sala S., Anton A., McLaren S.J., Notarnicola B., Saouter E. \& Sonesson U. (2017). In quest of reducing the environmental impacts of food production and consumption. Journal of Cleaner Production 140: 387-398.

DOI: https://doi.org/10.1016/j.jclepro.2016.09.054

Shackley S., Carter S., Knowles T., Middelink E., Haefele S. \& Haszeldine S. (2012). Sustainable gasificationbiochar systems? A case-study of rice-husk gasification in Cambodia, Part II: Field trial results,carbon abatement, economic assessment and conclusions. Energy Policy 41: 618-623.

DOI: https://doi.org/10.1016/j.enpol.2011.11.023

Sheehan J., Camobreco V., Duffield J., Graboski M. \& Shapouri H. (1998). Life Cycle Inventory of Biodiesel and Petroleum Diesel for Use in an Urban Bus. National Renewable Energy Laboratory, Golden, Colorado, USA.

DOI: https://doi.org/10.2172/1218369

Swarnasiri D.P.C. (2014). Quality evaluation of locally produced rice available in the open market of Sri Lanka: A case study 2012, Proceedings of the International Research Symposium on Postharvest Technology, pp. 44-49.

Wijesooriya, W.A.N. \& Priyadarshana, W.H.D. (2013). Structure, Conduct and Performance of Rice Milling Industry in Polonnaruwa and Hambantota Districts of Sri Lanka. Hector Kobbekaduwa Agrarian Research and Training Institute, Colombo 07.

Wijesundara S.M., Wickramasinghe A.D.B. \& Wijesundara C. (1990). Chemical and biofertilizers for rice, Proceedings of Rice Congress, Sri Lanka.

Wimberly J.E. (1983). Technical Handbook for the Paddy Rice Postharvest Industry in Developing Countries. International Rice Research Institute, Philippines.

www.alibaba.com, accessed in September 2019 